\title{
Marketing Management in Higher Education
}

\author{
Imanuddin Hasbi \\ Telkom University \\ iman.hasbi@gmail.com \\ Djam'an Satori \\ Universitas Pendidikan Indonesia \\ djamansatori@yahoo.com
}

\author{
Agus Rahayu \\ Universitas Pendidikan Indonesia \\ agus_rhy07@yahoo.co.id \\ Mohammad Fakry Gaffar \\ Universitas Pendidikan Indonesia \\ fakrygaffar@yahoo.com
}

\begin{abstract}
Marketing management problems faced by marketing higher education is getting tighter. This study is focused to examine in more detail the market, product, price, resources, competition, marketing strategies, satisfaction, loyalty, and growth of the higher education. The purpose of this study is to conduct a description, analysis, and design a management model effective marketing higher education and excel. This study uses qualitative research methods using instruments to uncover data through interviews, observation and documentation as well as using purposive sampling techniques. The findings of this study are: (1) Marketing higher education that succeed have the right target market; (2) The quality of study programs to realize the expectations of students and parents; (3) Target the right market is not sensitive to the cost of education; (4) The higher education resource development aims to satisfy the customer; (5) Higher education that winning the competition has a competitive advantage; (6) The formulation of appropriate marketing strategies to satisfy customers; (7) Higher education that satisfy customers maintain the quality of service and study programs; (8) A satisfied customer will faithfully promote word of mouth; (9) Customers are loyal to persuade potential students to go to higher education where tuition, so that growth and sustainable development of the higher education. The conclusions of this study are marketing management in higher education that excel able to determine the appropriate target market, obviously, so that customer service will satisfy customers who will be able to create loyal customers and impacting the growth of the higher education.
\end{abstract}

Keywords: Marketing Management, Higher Education Marketing, The growth of University.

\section{INTRODUCTION}

In the twenty-first century, higher education has been going through a changing rapidly. Change of the environment, the development of science, technology, as well as information systems that more rapidly encourage the birth of the paradigm of the world knows borderless.

In bargaining negotiations, the General Agreement on Trade in Service (GATS), the provision of education services is one of the 12 other services sectors are liberalized.
Higher education as part of the national education system to participate in providing human resources to the competitive advantage of the Indonesian nation with other nations. The dynamics of college to always perform continuous improvement towards a better and developed in accordance with the demands of global and national environment that is constantly changing. Higher education is respecting the factors are political, regulation, economic, sociological, technological, ecological, culture acting in a particular background.

The higher education is a non-profit organization because it has a social purpose and not for profit. Funds raised nonprofit organizations are often used to cover administrative expenses and operational, not to serve the target market. With marketing, higher education can increase its ability to serve customers satisfactorily, and higher education can survive and grow.

Based on data from the Ministry of National Education in 2011 [1] that:

The number of Indonesian students currently only 5.3 million people, 1 million between originating from universities, 3 million in private colleges, the remaining higher education official, religious and so on. The figure beyond those studying abroad. According to the estimates each year about 36 thousand Indonesian students going to college abroad. Indonesia was being assumed as a huge market for foreign universities. No wonder foreign countries vigorous promotion of higher education in Indonesia. Malaysia, Singapore, Japan, Australia, USA, UK, New Zealand, Taiwan, China, and European countries busy to hold the promotion of foreign education in Indonesia. They introduced a variety of advantages and facilities acquired if students continue their studies in the country. They also dare to offer a variety of scholarships and convenience. (http://mix.co.id/brand-

communication/branding/format-baru-persainganperguruan-tinggi-di-indonesia-3)

Growth in the number of universities in Indonesia leaps and bounds since the establishment of the new college, transfer in 
management, changes shape, or merger. In 2008 as many as 3,016 college consists of 83 state higher education and 2,933 private higher education spread to all regions in Indonesia. In 2012 there were 3,216 higher education consisting of 92 state higher education and 3,124 private higher educations as well as 16,755 study programs at state higher education and private higher education (the Directorate of Higher Education, August 1, 2012) [2]. Within 4 years increased 200 higher education consisting of 9 state higher education and 191 private higher educations.

Based on the research background which is the result of a preliminary study by documentation study and direct observation to higher education, higher education conducted carefully by investigators.

Enforce global free trade liberal education sector and commercial, some countries are already seeing the benefits of export of educational services into income countries.

Interest senior high school alumni prefer to enter state higher education compared private higher education because tuition fees are relatively cheap, the name and the reputation of the famous state universities, proud tuition at state universities with the good professor, and facilities, so that the private higher education is generally the second choice.

Capacity state higher education limitations, prospective students choose private higher education, private higher education vied appeal to prospective students and parents to study in higher education.

The amount of higher education in Indonesia competing for high school graduates or equivalent large by promoting the higher education through advertisements in the print media readership of regional and national, educational exhibits and go directly to the high school or equivalent, and through word of mouth. Higher education service in Indonesia is Tridharma includes: education, research, and community service. Based on the identification of the problem requires a college education proper marketing. Marketing is an organizational function and a set of processes for creating, communicating, and delivering value to customers and for managing customer relationship in ways benefit the organization and its stakeholders. Marketing management is the art and science of choosing target markets and getting, keeping, and growing customers through creating, delivering, and communicating superior customer value [3]. The focus of this study is marketing management in higher education. Based on the research background, which is the result of a preliminary study by documentation study and direct observation to universities, colleges conducted carefully by investigators.

\section{RESEARCH METHODOLOGY}

The method used is a qualitative method. Some of the terms used for qualitative research, namely research or inquiry naturalistic/scientific, ethnographic, interaction symbolic perspective into, ethnomethodology, the Chicago School, phenomenological, case studies, interpretive, ecological, and descriptive [4]

Inquiry that is grounded in the assumption that individuals construct social reality in the form of meanings and Interpretations, and that growing niche reviews these constructions to be transitory and situational. The dominant methodology is to discover meanings and interpretations reviews these cases by studying intensively in natural settings and by subjecting the resulting data is to analytic induction. [5]

\section{RESEARCH RESULTS AND THEIR DISCUSSION}

Higher education goes worldwide through a process characterized by significant changes both in educational demand and in the educational offer. Higher education institutions are put in a position to find solutions to problems arising from internal and external customer characteristics. The influence of market forces, whether the structure of higher education should be a quasi-market, state- controlled or a directed response to competitive forces [6], Market education consist of senior high school alumni, parent of students, and institution. Scopes of marketing higher education local, national, and international market. Higher education should be proactive in offering candidates help in choosing studies. This means believing prospective students' expectations and trying to reduce risks and anxieties related to making a decision.

The dozen thousands of higher education institutions in Indonesia compete freely and indeed fiercely on a local, national, and indeed international, basis for students, faculty and resources. Pricing varies substantially, both nominally the "list price" for tuition and net tuition discounted by financial aid. Competition between universities is getting tougher, better Intercollegiate State and Private Universities [7]. Intense competition as it is known on the broader economic scene is coming to higher education. It is important to recognize that competition can produce results that are both good and bad, both desirable and undesirable.

Higher education institution example public higher education institutions have a competitive advantage in costs over their higher-priced private and for-profit counterparts. Private and proprietary institutions counter this advantage by promoting their academic reputations, emphasizing convenient delivery of services, leveraging of financial aid, etc. Many private-sector institutions also have developed distinctive market niches.

Competition amongst higher education institutions is largely due to an oversupply of student places and slowing demand from suitably qualified students. As a result, managers in the higher education sector are seeking to rethink their strategic positions. The issue of quality is a central issue in question won the competition between Private Universities. 
Competitive advantage is more and more basing itself on intangible assets (the know-how and expertise of teaching staff, quality of lectures, team work, staff development), which the competition cannot acquire or successfully imitate in a short period of time. Hasan (2008) says that illustrates the competitive advantage that a company can do better than other companies even if they move in the same industry [8]. A higher education will be able to compete if it has a commitment to create and maintain the satisfaction of the stakeholders (students, parents of student, users). Competitive advantages develop over time due to quality graduates. If universities foster and remain in the fields in which they have a competitive advantage, they will continue to recruit top students and maintain funding at acceptable levels.

One of the most important add-on is the 7 Ps (Product, Price, Promotion, Place, People, Process, Physical evidence) approach [9]. Complexity of all marketing mix of higher education is service, price, distribution, promotion, people, physical evidence, and process. Application of a marketing strategy enables quality improvement in the system of higher education through synergistic application of marketing mix in order to create a service that corresponds to the expectations of target market and deliver a superior value. Marketing as proeducation [10].

Education as product. Offering higher education services involves special challenges because most services are intangible, inseparable, variable, and perishable. The essence of a service is a base for differentiation and expectation, as well as the user's behavior.

Promotion of higher education with target market requires a specific approach, since the decision on the choice of faculty is made once in a life-time. It is defined by time and the decision-making process depends on the family, friends, school and media and therefore it has to be created in a way in which a mixture of marketing communications influences stated segments of target public. Communications, environment, corporate behavior like reputation, innovation, financial, social responsibility, management quality, and brand equity shape the image of an educational institution, which, from a long-term aspect, provides competitive advantage and service user loyalty.

The price, as one of marketing mix instruments, should, at the same time, be considered as a significant element of educational institution strategic planning, which is often crucial when deciding which faculty to choose.

When defining marketing activities for higher education institutions, special attention must be paid to service distribution includes it is necessary to predefine attractive geographic frame, public transport, telecommunication, hot spot, in which service delivery will be in accordance with the needs and requirements of the target market.

The main goal of marketing in higher education institutions is to define quality education system, market-oriented, whereby one cannot ignore the institution primary role and function, which is to provide a specific type of service of general social benefit, in accordance with its needs. [11]

Marketing performance in higher education institutions, the ultimate goal of higher education should be external customer satisfaction (students, parents of students, employers, society, and enterprise users graduates) and internal customers (teaching and nonteaching staff) as a guarantee of sustainability of a market institution constantly changing. The approach of marketing educational services envisages the orientation to satisfying the customers' needs and using the marketing strategies to the level of university institutions which the education consumers will identify, who are interested in the educational offer for which they have capabilities and will allow adaptation to make it more attractive. The aim of higher education institutions must be the determination of needs, wishes, the education consumers' interests, the adaptation of educational and research approach to offer programs that maintain or improve long-term satisfaction of their and the society's interests.

Attracting students who are better suited to a given profile of studies will automatically contribute to lowering drop-out levels and raising the quality of education service, which largely depends on students' hard work and commitment. This will also have a bearing on students' satisfaction and will consequently raise their loyalty. Student loyalty is a critical measure in the success of higher-education institutions that aim at retaining and graduating students. Student loyalty is one of the major goals of educational institutions [12] . Creating loyal customer is at the heart of every business [13] . Effect of student loyalty is growth of higher education. Adapted definition marketing management by Kotler and Keller, marketing management in higher education is the art and science of choosing target markets higher education and getting, keeping, and growing customers through creating, delivering, and communicating superior customer value.

\section{CONCLUSION}

Higher education to survive and thrive in the market the obvious target market, have a captive market that is different, but it can limit the development of the university is becoming more widespread. The university should be open to all.

The study program and the graduates/alumni who are qualified and have a promising job prospects for the future as well as a high income to attract prospective students to study at a college.

The tuition fee on the target market of parents of students who belong to the upper middle class consciousness and high purchasing power to encourage their children to go to college as a provision for future of their children and for employees who are aware lectures to improve their competence; 


\section{B ATLANTIS PRESS}

The college continues to improve and develop resources include human resources, facilities and infrastructure, as well as financial resources. Efforts to increase and resource development facilities and infrastructure and financial resources are relatively more easily built up and improved earnings, but relatively easy and not take long for the university management to human resource development of lecturers in order to improve their competence take advanced education, research and write scientific papers in journals such as the national and international levels, in addition to improving the Functional Academic to a higher level.

Higher education competitive advantage depends on the uniqueness study programs through accreditation, competence of graduates promised, the job prospects of graduates, the quality of faculty and college facilities and infrastructure. The marketing strategy has an important role in the growth and blossoms higher education, forcing registrations marketing activities conducted three waves and sustainable.

Marketing management in higher education is the art and science of choosing target markets higher education and getting, keeping, and growing customers through creating, delivering, and communicating superior customer value.

\section{REFERENCES}

[1] the Ministry of National Education in 2011

[2] the Directorate of Higher Education, August 1, 2012

[3] Kotler, P. and Keller, K. (2012). Marketing management. Global edition, England: Pearson education.
[4] Bogdan, R., \& Biklen, S. K. (1982). Qualitative research for education: An introduction to theory and methods. Boston: Ally and Bacon.

[5] Gall, M.D., Gall, J.P., \& Borg, W.R. (2003). Educational Research: An Introduction. (Seventh Edition). Boston: Pearson Education, Inc.

[6] Aruman, Edhy. 13 Desember 2014. Format Baru Persaingan Perguruan Tinggi di Indonesia [online] http://mix.co.id/brandcommunication/branding/format-baru-persaingan-perguruan-tinggi-diindonesia-3.

[7] Gibbs, P. \& Maringe, F. (2009). Marketing higher education: theory and practice. New York: Mc Graw Hill.

[8] Umar, Husein. (2008). Strategic management in action: konsep, teori, dan teknik menganalisis manajemen strategis strategic business unit berdasarkan konsep Michael R. Porter, Fred R. David, dan WheelenHunger. Jakarta: Gramedia Pustaka Utama.

[9] Hasan, Ali. 2008. Marketing. Media Utama, Yogyakarta.

[10] Enache, I. C. (2011). Marketing higher education using the 7PS framework. In Bulletin of the Transilvania University Brasov, Vol. 4 (53), No. 1-2011 Retrieved from http://webbut.unitbv.ro/bu2011/Series\%20V/BULETIN\%20V\%20PDF/ 05\%20enache\%201\%20BUT\%202011.pdf

[11] Maringe, F. \& Gibbs, P. (2009). Marketing Higher Education: Theory and Practice. New York: McGraw-Hill.

[12] Gajic, J. (2012). Importance of Marketing Mix in Higher Education Institutions. Dalam Singidunum Journal, 2012, 9 (1): 29-41, ISSN 2217 8090, [Online], 13 halaman. Tersedia: Singidunum Journal of Applied Sciences

[13] Thomas, Sam. (2011). What Drives Student Loyalty in Universities: An Empirical Model from India. International Business Research, Retrieved from http://www.ccsenet.org/journal/index.php/ibr/article/viewFile/8925/709 94, No. 2; April 2011 